\title{
The Crisis in Darfur: A Short History
}

\section{Fekede Sileshi Fufa ${ }^{1 *}$, Tesema Ta'a ${ }^{2}$}

${ }^{1}$ College of Social Science Department of History, Sebeta Special Needs College of Teacher's Education, Ethiopia.

${ }^{2}$ College of Social Science, Department of History and Heritage Management Addis Ababa University, Ethiopia. fekede_sileshi@yahoo.com

Abstract: The main aim of this paper is to assess the political crisis happened in Darfur/Sudan. The paper is also review the ethnic conflict over economic interests and the response of Africa leaders with particular reference to the current Darfur crisis of 2003/04. The Darfur crisis began in 2003 and resulted in more than 2.7 million forced displacements of Darfurians and death of hundred thousands of the communities of the region. According to different humanitarian, organizations, writer and observers the estimated number of people who lost their lives due to this conflict ranges between 200,000-400,000. Over three-fourth of the villages in Darfur have been destroyed by Janjaweed militia. The Janjaweed militia began pillaging towns and villages inhabited by members of the African 'tribe' from which the rebel armies drew their strength in the Zaghawa, Masalit and Fur 'tribes'. Based on written sources the Janjaweed were well-equipped fighting force that enjoyed the obvious assistance of the Sudanese government in 2003. The 2003 Darfur crisis was causes for the deaths of hundred thousands of Darfurian, displacement, malnutrition, epidemic and various diseases. Due to the abovementioned problems various international actors were participated in the Darfur crisis to solve the existed difficulty.

Finally, in this paper emphasis is given to clarify the causes for the deaths of hundred thousands of Darfurian and displacement of the communities and the response of international governments and non-governmental organization to solve the problem. Here, the process of the Darfur crisis was not yet fully reconstructed. Recently many historians were tried to explain the problem of the war. As far as the abovementioned problems are concerned, however, those scholars have so far focused more on the activities of the conquerors rather than on the dilemma of the victims of war. The dilemma of Darfur crisis at the time of conflict were still need further investigation. So, the paper is present to fill the gap by cross-checking the gathered sources as a whole.

Keywords: Janjaweed, Rebel, Actors, Humanitarians, Tribe

\section{INTRODUCTION}

As we know Sudan is the largest country in the Africa, located in the north eastern part of the continent. Darfur (the land of Fur in Arabic) is one of the largest Sudanese territories located in the western Sudan. Darfur is a territory approximately the size of France and the largest region in terms of landmass and population size in Sudan. ${ }^{1}$ Based on written sources, Darfur was an independent state for several hundred years; it was incorporated into the Sudan by Anglo-Egyptian forces in 1916. ${ }^{2}$ Darfur is the home of 7.5 million population and the home of more than 80 ethnic groups and some of whom identified themselves as Arabs and others as non- Arabs (Black African). ${ }^{3}$

The predominant ethnic groups of west Darfur comprises mainly of the Fur, Masalit, and Zaghawa with a mixture of other ethnic groups, who often united in marriage with Arabs and other Africans. The Masalit are the majority $60 \%$ followed by the Arabs and other Africans namely Zaghawa, Erenga, Gimr, Dajo, Borgo and Fur. 'These sedentary Africans in Darfur have a history of clashes over land with pastoralist from Arab 'tribe'. While clashes over resources took place, they were usually resolved through negation between community 
leaders. ${ }^{5}$ Following the administrative divisions in 1994, Darfur has been divided into three provinces; North, South and West. ${ }^{6} \mathrm{~A}$ wide reaching 1994 administrative reorganization by the government of Sudan in Darfur gave members of Arab ethnic group's new positions of power which the Masalit, like their Fur and Zaghawa neighbors, saw as an attempt to undermine their traditional leadership role and the power of their communities in their homeland. ${ }^{7}$

Communal hostilities broke out in west Darfur among other places in 1998 and 1999 when Arab nomads began moving south with their flocks earlier than usual. During the 1998 clashes, more than sixty Masalit villages were burned, one Arab village was burned approximately sixty-nine Masalit and eleven Arabs were killed and more than 5000 Masalit were displaced, most fleeing either into Genuine town and Chad. ${ }^{8}$ Despite an agreement for compensation for both sides negotiated by local tribal leaders, clashes resumed in 1999 when nomadic herdsmen again moved south earlier than before. Then in 1999 clashes were even bloodier, with more than 125 Masalit villages partially or totally burned or evacuated and many hundred people killed, including a number of Arab tribal chiefs. ${ }^{9}$ The government brought in military forces in an attempt to quell the violence and appointed a military ma responsible for security overall, with the power to overrule even the west Darfur state governor. Many Masalit intellectuals and notables were arrested, imprisoned and tortured in the towns as government supported Arab militias began to attack Masalit villages; a number of Arab chiefs and civilians were also killed in this clashes. ${ }^{10}$

\section{The Aim OF THIS PAPER}

As indicated above, obviously the crimes against humanity have hence occurred in Darfur. Being on the world agenda has not yet led to meaningful steps to end the crisis. So what is it that has delayed the international responses and what positive essentials can be identified that can be built upon in countering to this and future emergencies. The paper is tried to assess how could this happened. I used qualitative methods to successfully accomplish this paper, which was collecting and analyzing necessary information about the history of the Crisis in Darfur. There were available published and unpublished documents related with the Crisis in Darfur. I used these documents after cross-checked with other related written materials to address the aim. These written sources were collected during my seminar research of 2012 and fieldwork from January-March 2013.

\section{RESULTS AND Discussion}

\section{The Immediate Cause of the 2003 Crisis in Darfur}

The current Darfur crisis began in February 2003; in western Sudan provinces which were complex and parts of the picture remain unclear. But several key factors are now well known. There are really numerous factors and elements in the context of this conflict. Of these factors, the immediate causes this conflict is derived from longstanding economic and political marginalization, scarcity of farmland and water resources caused by prolonged drought and desertification that drove northern Darfur nomadic Arab group into the Darfur area where African farming tribes settle. ${ }^{11}$

Apart from that, this conflict involved numerous factors such as, the dictatorship regime with bad government, luck of good governance, the availability, of weapons and a struggle for control resources competing for land and water. ${ }^{12}$ Above all, discrimination along ethnic lines, marginalization of the African tribes from the central government and uneven distribution of national wealth has a long history and has produced over violence in the Sudan..$^{13}$ The political marginalization of African communities in Darfur led to the formation of two prominent rebel groups the Justice and Equality Movement and the Sudan Liberation Army. ${ }^{14}$ The crisis erupted more in the early 2003 when two rebel groups aforementioned were emerged to challenge the National Islamic From government in Darfur. The Sudan Liberation Army and the Justice and Equality Movement claim the government 
of Sudan discriminates against black African ethnic groups in Darfur. ${ }^{15}$ They seek equitable development, land right, social and public services, democracy and regional autonomy rather than looking for succession like the south's Sudan People Liberation Army. ${ }^{16}$ In April 2003 the Sudan Liberation Army attacked El-Fasher air port and particularly since the escalation of the conflict, the government of Sudan has pursued a military strategy that has deliberately targeted civilians from the same ethnic groups as the rebels. ${ }^{17}$ Together the government and Arab Janjaweed militias targeted the Fur, Masalit and Zaghawa through a combination of indiscrimination and deliberate above ground bombardment, denial of access to humanitarian assistance, and scorched-earth tactics that displaced hundreds of thousands of civilian. ${ }^{18}$

In its recent report on the crisis in Darfur, the Human Right Watch a more balanced view of the urgency of the current crisis in Darfur and its correlation with recent western rebellion and previous conflicts in the region as follows:

The current conflicts in Darfur had deep roots. It is but the latest culmination of a protracted problem, yet there are key differences between the 2003-2004 conflicts and prior bouts of fighting. The current conflict has developed serious racial and ethnic overtones and clearly risks shattering historic if fragile pattern of co-existence. A number of ethnic groups previously neutral are now positioning themselves along the Arab/ African divide, aligning and co-operating with either the rebel movements or the government and its allied militia. Remaining neutral and outside the conflict is becoming impossible, through some groups have tried to do so. ${ }^{19}$

In addition to the aforementioned issue, different literatures also forwarded the current Darfur situation is termed as "the world's worst humanitarian crisis" or "genocide" by the United Nations and the United states respectively. The UN Commissioner for Human Right after a week-long travel around Darfur claimed that, the Darfur crisis is an outcome of the Sudanese government structural and overt violence against its people. ${ }^{20}$

\section{The Consequence of the Darfur Crisis}

The current Darfur crisis produced more than 2.7 million forced displacements of Darfurians causing them to move to other regions of Darfur or Sudan, or across borders, such as to eastern Chad and the death of hundred thousands. ${ }^{21}$ Concerning the Darfur crisis there are no reliable (the same) estimates of the number of people killed as a result of conflict. However, different materials and observers illustrated dissimilar information. According to these materials and observers the estimated numbers of people who died due to this conflict ranges between $200,000-400,000 .{ }^{22}$ For example, as some observers and US officials estimated that, more than 320,000 people are estimated to have died and at least 2.7 million displaced from their homes in Darfur by the end of $2004 .{ }^{23}$ According to the UN, as many as 300,000 people may have died since the beginning of the conflict. ${ }^{24}$

The government of Sudan has denied or severely restricted access to relief officials in Darfur and also, according to Mahammed Sahil, asserted that, the death has a result of this conflict estimates more than 200,000 and displaced of 2 million civilians within the Sudan and in the neighboring country, Chad and Central African Republic as a result of this conflict. ${ }^{25}$ In addition to this, according to the African Union Mission in Sudan the death toll by the late 2005 has reached as high as 400,000 and 2.7 million displacement. Over 2,300 Darfur villages were destroyed by the Janjaweed militia. Another figure made by the British Parliament concluded that the number of death in Darfur is $300,000 .^{26}$

While various countries and institutions have characterized the killing in Darfur as "genocide" including the United States Government and the crime in Darfur commenced in 2003, when Sudanese government forces and 
a militia force known as "Janjaweed" attacked primarily three African tribes; the Fur, Masalit, and Zaghawa in the rular areas of Darfur, a large area in western Sudan. ${ }^{27}$ since fighting broke out in 2003 between governments of Sudan forces, allied Janjaweed militia and other armed rebel groups. Killing such as the murder of civilians and the rape of women and girls have been widespread and continued, underscoring the necessity for urgent action. ${ }^{28}$ In addition to the abovementioned the consequence of the Darfur crisis, Thu Thi Quach forwarded as follow:

How the international community describes the situation, group murders, systematic rape, harassment, torching and looting villages in Darfur, which continued to claim more civilian lives and create insecurity in the region, requires more than international attention and humanitarian assistance. It demands decisive action to stop violence and human suffering. ${ }^{29}$

\section{Continental and International Peace Keeping Actors in Darfur}

The Darfur conflict provides an example in which the global community has completely failed in protecting the civilian genocide from the opposing militia. Taking the lead in intervening in the Darfur conflict has been the African Union. Although the AU does not have the resources to mount a fully effective intervention in Darfur, they have not applied much in the means of resolution at all. ${ }^{30}$ In 2004 the African Union established a small monitoring mission, the African Mission in Sudan in Darfur, consisting of some 60 monitors and 300 troops to protect them. In mid 2005, the number of troops increased to about $7000 .^{31}$ It did not mandate the actual protection of innocent civilians.

United Nation intervention was necessary to ensure that a coordinated properly resourced and legitimate international response to the conflict was implemented. The UN Security Council has adopted 26 resolutions since the start out the conflict in Darfur as well as sending constant warning to the Sudanese government. ${ }^{32}$ Although, all of these UN Security Council resolutions were passed, all were extremely difficult to operation in Darfur. With the resistance of the Sudanese government and the lack of a UN force or even a unified force to implement and ensure the changes the hope of ending the conflict seemed lost. So, while the UN Security Council made some great suggestion for ending the conflict in Darfur, they were in effective overall in ending the genocide. ${ }^{33}$ However, UN decided to establish an African Union-United Nation hybrid peacekeeping mission to Sudan. According to Mohammed "A joint UN-AU hybrid peacekeeping operation, also known as the UN-AU mission in Darfur and consist of 19,555 military personnel and an appropriate civilians component, including up to 3,772 police personnel is to be deployed". ${ }^{4}$

The European Union and NATO were also the two main international players in the resolution of the Darfur crisis. The European Union response to the Darfur is slightly different from US and more cautious. It has the European Union provided financial backing for the African Union Mission to Sudan in its attempt to end the confict. ${ }^{35}$ NATO has been assisting African Mission in Sudan in logistic and training. European Union and NATO have been major economic, humanitarians and diplomatic power in pushing the global response to the Darfur crisis. ${ }^{36}$

China is also another actor that could have serious economic power in pressurizing the government of Sudan. As in the southern Sudan potential oil exploitation is complicating the conflict in Darfur. Its petroleum companies are the major trading partner with Sudan. Two-third of Sudanese oil is bought by China. ${ }^{37}$ China has appointed an envoy to Darfur and she adopted "a policy of non-interference" in Sudan's domestic affair and its stand on the Darfur issue is that is must be resolved through "dialogue and negotiation". ${ }^{38}$ 
The US government, the American people and international organizations have been and are major actors in using all diplomatic and economic pressures on the government of Sudan to end all conflicts in the Sudan. ${ }^{39}$ it has maintained bilateral and multilateral sanctions on the government of Sudan, including arms embargoes, restrictions on imports, exports, and an asset freeze. However, it has yet to put real pressure on Khartoum for ending the sufferings of the Darfurians. ${ }^{40}$

\section{CONCLUSION}

As alluded, to the aforementioned section the political marginalization of African communities in Darfur led to the formation of prominent rebel groups. These are fighting against the oppression of the northern Sudanese government and aim to gain more right in terms of political participation. They "seek equitable development, land rights social and public services, democracy and regional autonomy" rather than looking for succession like South's. Contrary, Sudanese government defense force are involved in the Darfur conflict. Obviously in every countries the primary responsibility to protect its' criticize is government. In effect, the government of Sudanese is not unable but is unwilling to fulfill the responsibility to protect its citizens from international crimes against humanity, war crimes and the crime of genocide. Due to this, in January 2009 the International Criminal Court (ICC) issued to arrest warrants against president Omar al-Bashir, for suspected crimes against humanity and war crimes for allegedly coordinating killing in Darfur. In July 2010 a further arrest warrant was issued against the Sudanese president for genocide. Despite these warrants, al-Bashir has not yet been arrested by an International Criminal Court.

Finally this work has various significances; I hope it could create better understanding of the Darfur crisis and political history of the African people in general and that of Darfur region in particularly. It also helps understand the change during the period under study as a result of continuous interaction between the international actors and other African states. Therefore, I believe that my study account of Darfur Crisis will pave the way for further historical research by adding a brick to the Darfur crisis.

\section{ACKNOWLEDGMENT}

I would like to express my deepest gratitude and heartfelt thanks to my previous MA guest lecturer, professor Tesema Ta'a, for his timely and scholarly help in reading and correcting this paper. His corrections and critical comments from the preparation of the plan to the completion of my paper have been very useful and constructive. I am also greatly indebted to my entire friend, who have devoted their time and shared with me their experience and knowledge, without their contribution providing this paper could not have been possible.

\section{REFERENCES}

1. Mohammed Suliman (2006). The War in Darfur: The Resource Dimention. London. 8p, Eva, Dadrian (2004). Calling Genocide By Its Rightful Name, In Naming the Darfur Genocide. 248p.

2. William G. O, Neill and Violette, Cassis (2005). Protecting 2 Million Internally Displaced: The Success and Shortcoming of the African Union in Darfur. Brooking Institution, University of Bern, Project on International Displacment. 3p.

3. Darfur Relief and Documentation Center /DRDC (2010). $5^{\text {th }}$ Population and Housing Census in Sudan an Incomplete Exercise. Geneva, Switzerland.19p.

4. Human Right Watch (2004). Darfur Destroyed Ethnic Cleaning By Government Militia Forces in Western Sudan. 5p.

5. Kinfe Abraham (2005). Sudan The Politics of War and Peace. Ethiopia, Addis Ababa.537p. 
The Crisis in Darfur: A Short History

6. Jennifer, Traha (2008). Why The Killing in Darfur is Genocide. 995p.

7. Ibid.995-996

8. Human Right Watch (2004). 6p.

9. $\quad$ Ibid.7p.

10. Ibid.

11. Kinfe.535p.

12. William G. O, Neill and Violette, Cassis (2005).4p.

13. Thu Thi Quach (2004). The Crisis in Darfur: An Analysis of Its Origins and Storylines. Alexander, Verginia.9p.

14. Bob, Zaremba (2011). Conflict in Darfur: Calculation and Inadequate International Response. Michigan University. $45 p$

15. Ibid.

16. Ibid.

17. William G. O, Neill and Violette, Cassis (2005).4p.

18. Human Right Watch (2004). 7p

19. Ibid.8p

20. Thu Thi Quach (2004).1p

21. The Cultural Orientation Resource Center (2011). Refugees From Darfur: Their Background and Resettlement Needs. USA. 1-2pp.

22. Jennifer, Traha (2008).990p.

23. Ibid.

24. The Cultural Orientation Resource Center (2011).2p.

25. Mohammed Salih (2007). The Greater Horn of Africa: A Desk Study Prepared For the UNESCO'S “Greater Horn Horizon Initiative.1p.

26. William G. O, Neill and Violette, Cassis (2005).13p.

27. Human Right Watch (2004). 7p.

28. Jennifer, Traha (2008).995-96pp.

29. Thu Thi Quach (2004).1p.

30. Bob, Zaremba (2011).52p.

31. Sarwar,N (2009). Darfur Crisis: Why has the UN Failed?.7p.

32. Bob, Zaremba (2011).54p.

33. Ibid.55-56pp

34. Mohammed Salih (2007).38p

American Research Journal of History and Culture

Page 6 
The Crisis in Darfur: A Short History

35. European Union Crisis in Darfur and European Commission's Response.2006.1-2pp.

36. Bob, Zaremba (2011).52-53pp

37. Ap and Sudan Tribune (2007). Sudan Divestment Campaign Over Darfur Goes Global. 1p.

38. Reuters (2007). China, Russia Breach Darfur Arms Embergo.8p.

39. Bob, Zaremba (2011).53p

40. Sarwar,N (2009).8p.

Citation: Fekede Sileshi Fufa, Tesema Ta'a. "The Crisis in Darfur: A Short History". American Research Journal of History and Culture ; V4, I1; pp: 1-7

Copyright (C) 2018 Fekede Sileshi Fufa, Tesema Ta'a. This is an open access article distributed under the Creative Commons Attribution License, which permits unrestricted use, distribution, and reproduction in any medium, provided the original work is properly cited. 